Please do not remove this page

RMIT

UNIVERSITY

\title{
An operational risk profile: the experience of British firms
}

Moosa, Imad; Li, Larry

https://researchrepository.rmit.edu.au/esploro/outputs/9921858310101341/filesAndLinks?institution=61RMIT_INST\&index=null

Moosa, I., \& Li, L. (2013). An operational risk profile: the experience of British firms. Applied Economics, 45(17), 2491-2500. https://doi.org/10.1080/00036846.2012.667556

Document Version: Accepted Manuscript

Published Version: https://doi.org/10.1080/00036846.2012.667556

Repository homepage: https://researchrepository.rmit.edu.au

(C) 2013 Taylor and Francis

Downloaded On 2023/04/26 19:33:02 +1000

Please do not remove this page 
Thank you for downloading this document from the RMIT Research Repository.

The RMIT Research Repository is an open access database showcasing the research outputs of RMIT University researchers.

RMIT Research Repository: http://researchbank.rmit.edu.au/

\section{Citation:}

Moosa, I and Li, L 2013, 'An operational risk profile: the experience of British firms', Applied Economics, vol. 45, no. 17, pp. 2491-2500.

See this record in the RMIT Research Repository at:

http://researchbank.rmit.edu.au/view/rmit:14992

Version: Accepted Manuscript

Copyright Statement: (c) 2012 Taylor and Francis Group, LLC

Link to Published Version:

http://dx.doi.org/10.1080/00036846.2012.667556 


\title{
An Operational Risk Profile: The Experience of British Firms ${ }^{\#}$
}

\author{
IMAD MOOSA AND LARRY LI ${ }^{*}$ \\ SCHOOL OF ECONOMICS, FinANCE AND MARKETING \\ RMIT
}

\begin{abstract}
This study provides an analysis of 163 operational loss events experienced by a variety of British firms over the period 1999-2008. Ten different hypotheses are tested to examine the distribution of loss severity and frequency with respect to business line, event type and corporate entity type. We also test hypotheses on the relation between loss severity and the decline in the market value of the announcing firm and whether or not the decline in market value is greater if the loss results from internal fraud. The results indicate that loss severity does not depend on firm size, that the decline in market value bears no stable relation to the loss amount and that they decline in market value relative to the loss amount is positively related to firm size.
\end{abstract}

\section{JEL Classification: G21}

Keywords: Operational Risk, Basel II, Operational Loss Events, Business Lines

\footnotetext{
\# The first author is grateful to the Australian Research Council for the Discovery Grant used to finance work on this project. We would like to thank an anonymous referee for useful comments.

* The corresponding author. Address: School of Economics, Finance and Marketing, RMIT, 239

Bourke Street, Melbourne, Victoria 3000, Australia. E-mail:larry.li@rmit.edu.au.
} 


\section{Introduction}

Operational risk is the risk of (operational) losses resulting from the failure of people, processes and from external factors. The particular significance assigned to operational risk is motivated by the spectacular and widely publicised corporate collapses that surface regularly. It was not until the early 1990s (and possibly the mid1990s, following the collapse of Barings Bank) that the term "operational risk" was coined. Power (2005) attributes the emergence of this term to the publication of the Basel II proposals, ${ }^{1}$ but he suggests that Nick Leeson, the rogue trader who brought down Barings, was "the true author and unwitting inventor of operational risk, since most discussions of the topic refer to this case as a defining moment". ${ }^{2}$ This should not be taken to imply that operational risk is limited to banks, as it covers firms of all types, more so than either market risk and credit risk. ${ }^{3}$

Interest in operational risk can be attributed to the fact that it can be fatal. Blunden (2003) argues that operational risk is as likely to bring a company to its knees as a market collapse, although it is within management control in many cases (certainly so in the case of Barings). Kilavuka (2008) points out that "the impact of operational failure can be far reaching” and that “a firm’s long-term viability can be impaired by operational failures, regardless of whether the immediate losses are sustainable in the short term”. He further argues that the impact of operational failure may be augmented by (i) the disruption of services, which could lead to severe erosion of customer

\footnotetext{
${ }^{1}$ Basel II introduced new provisions to deal with operational risk in banks—see for example Petersen and Mukuddem-Petersen (2005) for the effect of introducing Basel II on the riskiness of bank assets and de Mendonca et al. (2011) for the estimation of capital requirements for operational risk.

${ }^{2}$ Nick Leeson was not really the inventor of operational risk because the presence of operational risk predates Leeson. A more valid statement would be that the Nick Leeson story was a major reason for the growing interest in operational risk.

${ }^{3}$ The sinking of the Titanic and wiping out of the dinosaurs were two catastrophic operational loss events. The first occurred because of the failure of people, systems, processes and an external factor (the iceberg), whereas the second was entirely due to an external factor, the asteroid.
} 
loyalty; and (ii) litigation, which could damage irrevocably a firm’s reputation and brand even if the legal cost can be easily supported by the firm's resources. Atik (2009) suggests that reputational risk refers to both the prospect of a decline in goodwill and the possibility of feeling constrained to undertake certain transactions for the purpose of maintaining goodwill. Because of the general nature and diversity of operational risk, this study covers not only banks and financial institutions but rather a diversified set of firms falling under different corporate classifications.

The objective of this paper is to analyse the operational losses experienced by some British firms over the period 1999-2008. Empirical work is carried out to test some hypotheses pertaining to the relation between operational losses and firm characteristics such as size and leverage. We examine the possibility of interdependence between the frequency (number) and severity (amount) of losses incurred in a particular business line and the type of the underlying loss event and whether or not the corporate entity type does matter. The paper also covers an issue that has not been dealt with in previous studies - that of the relation between operational losses and leverage. Most related empirical studies concentrate on the relation between operational losses and frm size, an issue on which some empirical evidence is presented in this paper.

\section{Literature Review}

Empirical studies of operational risk have shown that a firm can suffer a market value decline in the days surrounding the announcement of a large loss that is significantly larger than the loss itself. One of the earliest studies dealing with this issue is that of Karpoff and Lott (1993) who analysed the reputational losses that firms experience 
when they face criminal fraud charges. By using events of this sort that occurred over the period 1978-1987, they find that alleged or actual corporate fraud announcements produce statistically significant losses in the underlying firm's market value. They attribute a small portion of any loss (about 5.5 per cent) to legal fees and penalties. It is suggested that a large portion of a loss reflects higher expected penalties for future fraud and the profits lost because of the committed fraud, whereas the remaining portion represents lost reputation.

Wei (2003) conducted an empirical study of operational risk in the insurance industry to test several hypotheses pertaining to the effect of operational loss announcements. By using data from the OpVar operational loss database, he found results indicating that operational loss events have a significantly negative effect on the market value of the affected insurers and that the effect of operational losses goes beyond the firm that incurs them. In another study, Wei (2006) examined the impact of operational loss events on the market value of announcing and non-announcing U.S. financial institutions using data from the OpVar database. The results reveal a significantly negative impact of the announcement of operational losses on stock prices. He also found that the decline in market value significantly exceeds the operational losses causing them.

Murphy et al. (2004) examined the market impact on firms alleged to have committed acts of misconduct such as antitrust violations, bribery, fraud and copyright infringement. Out of these types of misconduct, fraud was found to have the most 
significant adverse effect on stock prices. ${ }^{4}$ They also found firm size to be negatively related to the percentage loss in the market value and that allegations of misconduct are accompanied by increased variability of stock returns. The influence of firm size on market losses is attributed to both an economy-of-scale effect and a reputational effect. Palmrose et al. (2004) also found market reaction to loss announcement to be more negative for restatements involving fraud.

Perry and de Fontnouvelle (2005) explain the observation that a firm can suffer a market value decline in excess of the operational loss itself in terms of the indirect impact of reputational risk, because disclosure of fraudulent activity or improper business practices at a firm may damage the firm's reputation. They measure reputational losses by examining a firm's price reaction to the announcement of a major loss event, assuming that a reputational loss has occurred when the firm's market value declines by more than the announced loss amount. They found that market values fall one-for-one with losses caused by external events, but fall by over twice the loss percentage in cases involving internal fraud. They contend that their results imply a reputational impact for losses due to internal fraud while externallycaused losses have no reputational impact. This argument means that only internal fraud causes reputational loss, which is difficult to substantiate. We will come back to this point later.

Cummins et al. (2006) assess the market value impact of operational loss announcements by U.S. banks and insurance companies. Their results reveal that market values respond negatively to operational loss announcements, with insurance

\footnotetext{
${ }^{4}$ It is not clear why "fraud" and "bribery" are listed as two separate items when bribery is a kind of fraud. According to the BCBS classification of operational loss events, bribes and kickbacks are classified under internal fraud (see, for example, Moosa, 2007, p 100).
} 
stocks having a stronger reaction than bank stocks. They also found a positive relation between losses and Tobin’s Q, suggesting that operational loss announcements have a more significant market impact for institutions with better growth prospects. The results revealed that market value losses are more severe than the announced losses, which-according to the Perry and de Fontnouvelle (2005) argument-indicates reputational losses were involved.

An issue that has received considerable attention is the hypothesised relation between operational losses and firm size. This proposition is used to justify the basic indicators approach to the calculation of the operational risk capital charge under Basel II, where size is proxied by gross income. ${ }^{5}$ Murphy et al. (2004) explain the relation between loss severity and size in terms of economies of scale and reputational effects.

Herring (2002) casts doubt on the usefulness of the basic indicators approach for the calculation of the capital charge as a percentage of gross income. He argues that it is doubtful if gross income captures even the scale of an institution's operations adequately and that it has no tenuous link to the risk of an expected loss due to internal or external events. Pezier (2003) suggests that the connection between gross income (hence size) and operational risk is loose: "gross income is about the past whereas operational risk is about the future". de Fontnouvelle et al. (2005) describe measurement based on a volume indicator as measurement in "an ad hoc manner". Jobst (2007) argues that relating operational risk exposure to business volume amounts to an incomplete regulatory measure that engenders misleading conclusions about operational risk exposure and the associated capital charges.

\footnotetext{
${ }^{5}$ Under the basic indicators approach of Basel II, the capital charge against operational risk is calculated as 15 per cent of the average gross income over the past three years.
} 
McConnell (2008) is sceptical of the relation between operational losses and gross income (as a measure of size) by using two operational loss events: the terrorist attack on the World Trade Center in 2001 and the foreign exchange losses of the National Australia Bank (NAB) in January 2004. The severity of the losses caused by the attack on the World Trade Center were less than 5 per cent of the average gross income for the largest 15 U.S. banks. The reported losses incurred by NAB are only 3.8 per cent of the gross income of the big four Australian banks according to their 2005 reports. McConnell argues that "there would have to be something in the order of one NABsize event each and every quarter to consume the BIA-calculated capital for each major bank”. Sundmacher (2007) believes that gross income would not have reflected the actual risk taken in situations resulting in high-profile operational losses, such as Barings and the Allied Irish Bank. However, Chernobai et al. (2007) demonstrate that firm-specific characteristics (such as size) are highly significant in their models.

Shih et al. (2000) examined the relation between losses and firm size, where size is proxied by revenue, assets and the number of employees. By estimating a logarithmic specification relating the loss amount to firm size using OpVaR data of 4700 loss events, they reached a number of conclusions, including the following: (i) the magnitude of loss is related to the size of the firm but the relation is nonlinear; (ii) size accounts for a very small portion of the variability in loss severity; and (iii) revenue is more correlated with loss size than either assets or the number of employees. They conclude that the weak relation between size and loss amount can be attributed to factors such as inherent differences in risk (based on the type of business), management competence (or lack thereof) and the quality of the internal control 
environment. This sentiment is shared by Aue and Kalkbrener (2007) who refer to evidence based on a regression analysis of Opvantage data performed at Deutsche Bank, which produced "no significant relationship between the size of a bank and the severity of its losses”. However, Wei (2007) argues that there is indeed some connection between size and the severity of losses, pointing out that "a bank with $\$ 1$ trillion assets is probably more likely to have more and larger losses than a bank with \$100 million assets”. He produces cross-sectional regression results showing a positive and statistically significant relation between the logarithm of losses and the logarithm of assets. Thus, the evidence is, at best, mixed.

Moosa and Silvapulle (2011) conducted a comprehensive study of 54 operational loss events experienced by eight Australian banks during the period 1990-2007. Their results show that the announcement of operational losses has an adverse effect on the stock price and market value of the announcing bank and that no systematic relation is present between losses and bank characteristics such as size and leverage. They also show that while the frequency of an event of a certain type is independent of the underlying business line, there is an association between the loss amount and the business line. The decline in market value relative to the loss amount is found to be independent of the type of the underlying loss event.

\section{Hypotheses and Methodology}

The literature review provides a list of ten hypotheses that we test in this study. The hypotheses can be stated as follows: 
Hypothesis 1: The severity of a loss event of a certain type is independent of the business line.

Hypothesis 2: The frequency of a loss event of a certain type is independent of the business line.

Hypothesis 3: The severity of a loss event of a certain type is independent of the corporate entity type.

Hypothesis 4: The frequency of a loss event of a certain type is independent of the corporate entity type.

Hypothesis 5: The decline in the market value of a firm resulting from the announcement of a loss event is not greater than the loss itself.

Hypothesis 6: The decline in the market value of a firm relative to the loss amount is not greater when the loss event involves internal fraud.

Hypothesis 7: The average loss resulting from an event involving internal fraud is not greater than the average loss resulting from other event types.

Hypothesis 8: The decline in the market value of a firm depends on the size of the firm.

Hypothesis 9: The decline in the market value of a firm depends on the loss amount.

Hypothesis 10: The decline in the market value of a firm relative to the operational loss depends on size and leverage.

Hypotheses 1-4 are tested to find out if the frequency and severity of events of certain types are greater in certain business lines or corporate entity types than in others. They are tested by constructing $n \times m$ contingency tables (containing $n$ rows and $m$ columns). For hypotheses 1 and 2, the rows and columns represent event types and business lines, respectively. For hypotheses 3 and 4, the rows represent corporate 
entity types whereas the columns represent event types. If $O_{i j}$ is the cell falling in row $i$ and column $j$, then

$$
\left.\begin{array}{l}
R_{i}=\sum_{j=1}^{m} O_{i j} \\
C_{j}=\sum_{i=1}^{n} O_{i j}
\end{array}\right\}
$$

Hence the total number of observations, $N$, is given by

$$
N=\sum_{i=1}^{n} R_{i}=\sum_{j=1}^{m} C_{j}
$$

Under the null that there is no association between rows and columns, the estimated value of the observation in each cell is given by

$$
E_{i j}=\frac{R_{i} C_{j}}{N}
$$

for $i=1, \ldots . . n$ and $j=1, \ldots . . m$. The test is based on the magnitudes of the actual observations, $O_{i j}$, and the expected values of these observations, $E_{i j}$. The null of no association is rejected if

$$
\sum_{i=1}^{n} \sum_{j=1}^{m} \frac{\left(O_{i j}-E_{i j}\right)^{2}}{E_{i j}}>\chi^{2}((n-1)(m-1))
$$

Rejection of the null hypothesis implies that the frequency or severity of events of a certain type tend to be greater in certain business lines or corporate entity type than in others.

Testing Hypothesis 5 boils down to testing the null $\hat{p}=p_{0}$ against the alternative $\hat{p}>p_{0}$, where $\hat{p}$ is the estimated proportion of firms exhibiting a decline in market value that exceeds the loss amount and $p_{0}$ is a threshold. $\hat{p}$ is calculated as 


$$
\hat{p}=\frac{\sum_{i=1}^{N} x_{1, i}}{\sum_{i=1}^{N} x_{1, i}+\sum_{i=1}^{N} x_{2, i}}
$$

where $N$ is the sample size. $x_{1, i}$ takes the value of 1 if $\Delta V_{i}>L_{i}$ and 0 otherwise, while $x_{2, i}$ takes the value of 1 if $\Delta V_{i}<L_{i}$ and 0 otherwise. The change in market value (measured as the share price multiplied by the outstanding number of shares) is calculated as

$$
\Delta V_{i}=\max \left(V_{t-5}, V_{t-4}, \ldots . V_{t-1}\right)-\min \left(V_{t}, V_{t+1}, \ldots . V_{t+5}\right)
$$

where $V_{t-j}$ is the value $j$ days before the announcement of the loss event, $V_{t}$ is value on the announcement day and $V_{t+j}$ is value $j$ days after the announcement day. The null is rejected in favour of the alternative at the 5 per cent significance level if

$$
z=\frac{\hat{p}-p_{0}}{\sqrt{\frac{p_{0}\left(1-p_{0}\right)}{N}}}>1.67
$$

Hypothesis 6 is that the decline in market value relative to the loss amount $(\Delta V / L)$ is greater when the loss event involves internal fraud. This hypothesis is tested on the basis of the difference between the mean value of $\Delta V / L$ associated internal fraud and that resulting from other kinds of events. Define the sample means of losses associated with internal fraud and those associated with other loss events as

$$
\begin{aligned}
& \bar{X}_{1}=\frac{\sum_{i=1}^{N}\left[\left(\frac{\Delta V_{i}}{L_{i}}\right) \mid L_{i}=f(I F)\right]}{n_{1}} \\
& \bar{X}_{2}=\frac{\sum_{i=1}^{N}\left[\left(\frac{\Delta V_{i}}{L_{i}}\right) L_{i} \neq f(I F)\right]}{n_{2}}
\end{aligned}
$$


where $L_{i}=f(I F)$ indicates that the loss event involves internal fraud and $L_{i} \neq f(I F)$ indicates that the loss event does involve internal fraud. $n_{1}$ and $n_{2}$ are the sample sizes associated with $L_{i}=f(I F)$ and $L_{i} \neq f(I F)$, respectively. They are calculated as

$$
\begin{aligned}
& n_{1}=\sum_{i=1}^{N} x_{1, i} \\
& n_{2}=\sum_{i=1}^{N} x_{21, i}
\end{aligned}
$$

where $x_{1, i}$ takes the value of 1 if $L_{i}=f(I F)$ and 0 otherwise, while $x_{2, i}$ takes the value of 1 if $L_{i} \neq f(I F)$ and 0 otherwise. The null hypothesis of the equality if the sample means, $\mu_{1}=\mu_{2}$, is rejected against the alternative $\mu_{1}>\mu_{2}$ if

$$
\frac{\bar{X}_{1}-\bar{X}_{2}}{\hat{\sigma}} \sqrt{\frac{n_{1} n_{2}}{n_{1}+n_{2}}}>t\left(n_{1}+n_{2}-2\right)
$$

where $t\left(n_{1}+n_{2}-2\right)$ is the critical value of the $t$ distribution with $n_{1}+n_{2}-2$ degrees of freedom and

$$
\hat{\sigma}=\sqrt{\frac{n_{1} s_{1}^{2}+n_{2} s_{2}^{2}}{n_{1}+n_{2}-2}}
$$

where $s_{1}^{2}$ and $s_{2}^{2}$ are is the estimated sample variances. Hypothesis 7 is tested in the same manner, except that $\Delta V_{i} / L_{i}$ is replaced by $L_{i}$.

Hypotheses 8-10 are tested by estimating the regression equations

$$
\begin{aligned}
& L_{i}=\alpha_{1}+\beta_{1} A_{i}+\varepsilon_{1 i} \\
& \Delta V_{i}=\alpha_{2}+\beta_{2} L_{i}+\varepsilon_{2 i}
\end{aligned}
$$




$$
\left(\frac{\Delta V_{i}}{L_{i}}\right)=\alpha_{3}+\beta_{3} A_{i}+\gamma_{3}\left(\frac{A_{i}}{E_{i}}\right)+\varepsilon_{3 i}
$$

where $A$ is total assets, used as a proxy for size in preference to gross revenue or other measures of scale (such as the number of employees), and $E$ is shareholders equityhence $A / E$ is the leverage ratio.

\section{A Description of the Operational Loss Events}

Data on the operational losses endured by British firms were obtained from the Fitch (First) qualitative database, which contains long write-ups and useful information about loss events obtained from multiple sources. This database provides a comprehensive analysis of the circumstances under which loss events occur, but no supplementary data on the underlying firms are provided. The focus of qualitative databases is not on capturing every event that takes place but rather to examine events that are of greater relevance and interest to subscribers.

The data sample comprises 163 loss events recorded over the period 1999-2008. Figure 1 shows the frequency (number) and severity (amount) of the loss events year by year. The highest number of events was recorded in 2007, but the most severe loss events happened in 2002 with a total loss of USD7.55 billion. ${ }^{6}$ Average severity was also highest at USD539 million in 2002. Only four loss events were recorded for 2008, valued at USD14.8 billion, which may sound strange because 2008 was the peak of the global financial crisis. At least two explanations can be put forward for this anomaly. First, not all loss events occurring in one year are recorded. The second explanation is that the losses incurred during the initial stages of the global financial

\footnotetext{
${ }^{6}$ The loss amounts are expressed in U.S. dollar terms because this is how they are reported on the database.
} 
crisis were predominantly market losses (asset write-downs) and credit losses resulting from default on loans (including mortgages) and deterioration of the market values of assets used as collateral.

Table 1 and Figure 2 show the frequency and severity of the loss events classified by business line and event type, as suggested by the Basel Committee on Banking Supervision (BCBS) for the implementation of Basel II. Apart from “others”, most of the loss events happened in trading and sales, while the most severe events were associated with asset management, predominantly taking the form of clients, products and business practices. In terms of severity, most of the losses are classified under "other” because the classification mainly pertains of financial institutions, hence there is a large number of big events that are "unclassified". Table 1 forms the basis of constructing the $7 \times 7$ contingency table used to test hypotheses 1 and 2 .

Table 2 displays the classification of losses in terms of severity and frequency by event type and corporate entity type. We can see that big losses were endured by commercial banks, the sector that also witnessed the largest number of losses. Out of non-financial firms, two losses endured by telecommunication firms were worth USD6.3 billion. In terms of average severity, the telecommunication sector came on top, with publishing and media in second place and transportation in third place. Table 2 is the basis of testing hypotheses 3 and 4 by constructing a $20 \times 7$ contingency table.

Figure 3 shows the distribution of losses in terms of frequency and severity among broader sectors: financial, non-financial and services. In terms of frequency, the financial sector endured 86 per cent of the loss events. In terms of severity, the 
financial and non-financial sectors were almost on equal footing. These figures actually raise an important question as to why Basel II mainly deals with a subset of the financial sector, banks, when non-financial firms are just as vulnerable to operational risk.

\section{Empirical Results}

The results of testing hypotheses 1-4 are presented in Table 3, showing test statistics, the associated degrees of freedom and the critical values of the test statistics. All of the hypotheses are rejected, implying the following: (i) operational losses of certain types tend to be more severe and/or more frequent in certain business lines; and (ii) they tend to be so in corporate entities of certain types. For example, losses resulting from internal fraud and from clients, products and business practices tend to be more severe in asset management and more frequent in asset management and in trading and sales. The results also mean that the incidence of operational losses is not equally distributed among firms with different corporate types. In terms of severity, losses resulting from clients, products and business practices are more severe in commercial banks but internal fraud is more severe in publishing and media. Also, the fact that a large percentage of the loss events are classified under "others" shows that the BCBS classification is not universal, even for financial institutions on their own.

The results of testing Hypothesis 5 are described by Figure 4, which shows a plot of the test statistic for various values of $p_{0}$ against the 5 per cent critical value. The results show that the null hypothesis cannot be rejected for values of $p_{0}$ slightly over 0.5. This means that the decline in market value as a result of the announcement of an operational loss is not predominantly greater than the loss itself: it may be greater or 
smaller. This result is in contrast with the finding of Wei (2003) that the decline in market value significantly exceeds the operational losses causing them. It is also inconsistent with the proposition put forward by Perry and de Fontnouvelle (2005) that the decline in market value is equal to or greater than the announced loss, depending on whether or not a reputational loss is endured. It is, however, hazardous to assume that the difference between the decline in market value and the loss that triggers it is a reputational loss. Furthermore, there is no reason to suggest that in the absence of reputational loss, the decline in market value is equal to the announced loss. The severity of operational losses and the decline in market value are determined by independent factors, a point that we will come back to later.

The results of testing hypotheses 6 and 7 are reported in Table 4 . Neither of the two hypotheses can be rejected, implying that loss severity and the decline in market value relative to the loss are not greater in event involving internal fraud. This means that internal fraud does not cause proportionately greater losses in market value or greater operational losses than other events. This result is in contrast with the findings of Perry and de Fontnouvelle (2005), Cummins et al. (2006), Karpoff and Lott (1993), Murphy et al. (2004), and Palmrose (2004). Since it is not an easy task to explain why internal fraud causes a greater loss of market value than other events, our results sound more plausible.

Perry and de Fontnouvelle (2005) suggest that the market value of an announcing firm falls one-to-one with the announced loss except when internal fraud is the cause. In this case, they point out, the fall in market value is "over twice the loss". They attribute the difference between the effect of internal fraud and that of other loss 
events to the observation that reputational loss results only from internal fraud. This argument is not plausible because a firm may endure a loss of reputation for reasons other than internal fraud. For example, external fraud is as likely as internal fraud to cause a reputational loss. Losses resulting from external events may cause reputational losses if the way the event is handled is taken to imply management incompetence. ${ }^{7}$ Losses resulting from fiduciary risk $^{8}$ could cause reputational loss and so could computer glitches, antitrust violations, workplace safety problems, and almost any kind of operational loss event. ${ }^{9}$ For example, Kilavuka (2008) attributes the loss of reputation to disruption of services and litigation, both of which could be the product of operational failure.

The results of testing hypotheses 8-10 are reported in Table 5. Equation (14) has a rather low explanatory power and an insignificant coefficient on the explanatory variable. ${ }^{10}$ The conclusion that can be derived from this result is that operational losses do not depend on size, a finding that casts doubt on the validity of the basic indicators approach of Basel II. This result supports the findings of most of the previous studies of the relation between loss severity and size.

\footnotetext{
${ }^{7}$ During the global financial crisis, which is an external event that hit banks all over the world, reputational loss was evident but it varied from one bank to another and from one country to another (for example, Atik, 2009). Australian banks have not endured the loss of reputation endured by U.S., British, Icelandic and even some Swiss and German banks. In the U.S. Citigroup lost more of its reputation than the Bank of America, while in the U.K. the biggest losses of reputation were endured by the Royal Bank of Scotland and Northern Rock. Bank runs typically result from the loss of reputation, not necessarily because of fraud but perhaps because of illiquidity or mass default.

${ }^{8}$ Fiduciary risk is the risk of losses resulting from selling a product that is different from what has been advertised. Massive product recalls cause significant reputational losses, although no fraud is involved.

${ }^{9}$ In 2010, BP endured a massive reputational loss because of a fire on an offshore oil rig. When a new CEO was appointed in July, the first thing he promised was to "restore the shattered image of BP”. No fraud was involved in this case either.

${ }^{10}$ A logarithmic specification was also tried but the results turned out to be even worse.
} 
The results of estimating equation (15) show that the decline in market value does not depend on the loss amount, which confirms the earlier finding derived from testing Hypothesis 5. This result is consistent with the findings of Moosa and Silvapulle (2011). However, it is not consistent with the proposition put forward by Perry and de Fontnouvelle (2005) that, except for internal fraud, the market value of the announcing firms fall "one for one" with the operational loss amount. This, however, is an assertion that does not market sense. The fall in market value results from declining stock prices as investors rush to sell the stock of the loss announcing firm. For market value to fall by an amount that is equal to the loss, the increase in the supply of stock must be such that it causes a decline in the stock price that produces a fall in market value equal (or approximately equal) to the announced loss. This proposition cannot be substantiated by intuition or rigorous theoretical reasoning, neither is it supported by empirical evidence. After all, the fall in market value and operational losses are not related by an exact formula that is derived from financial statements. Rather, they are related as in Equation (15).

The finding that the decline in market value bears no stable relation to the loss amount, coupled with the earlier finding that the loss amount is not related to firm size, means that the decline in market value is not related to size. This finding is inconsistent with the result obtained by Murphy et al. (2004), which indicates a negative relation between the decline in market value and firm size. In any case, one would expect that such a relation would be positive, as pointed out by Wei (2007).

The results of estimating equation (16) show that the decline in market value relative to the loss amount bears a significantly positive relation to size but it is not related to 
leverage as envisaged by Chernobai et al. (2007). The explanation of the finding of a positive relation with size is straightforward. Loss events involving large firms are more highly publicised and receive greater public scrutiny than those involving small firms. Hence, a large firm endures a more serious rush to sell its stocks, and consequently a more significant decline in market value, than a small firm. While loss severity is not related to size, the decline in market value relative to the loss is. While leverage should be a determinant of the decline in market value relative to the loss amount, the finding of no relation can be explained as follows. When a loss event is announced, investors rush to sell the stocks of the announcing firm without taking time to consider leverage.

\section{Conclusion}

The analysis of 163 major operational loss events experienced by British firms over the period 1999-2008 reveal the following findings:

1. Operational losses of certain types tend to be more severe and/or more frequent in certain business lines and certain corporate entity types.

2. The decline in the market value of a firm following the announcement of an operational loss may or may not be greater than the loss amount.

3. Loss severity and the decline in market value relative to the loss amount are not necessarily greater when the loss results from internal fraud.

4. Loss severity does not depend on the announcing firm's size.

5. The decline in market value does not depend on the loss amount.

6. The decline in market value relative to the loss amount is unrelated to leverage but it is positively related to size. 
These results support the findings of some previous studies but they are inconsistent with the findings of others. For example, our results do not show strong or unequivocal support for the findings of Perry and Fontnouvelle (2005), Palmroes (2004) and Murphy et al. (2004) that losses caused by internal fraud tend to be greater than those associated with other loss events. The findings of Cummins et al. (2006) and Wei (2003) show that the decline in market value is greater than the causing loss is likewise not supported strongly by our results. Our finding on the relation between operational losses and firm size supports the proposition put forward by Herring (2002), Peizier (2003) and McConnell (2008) against the basic indicators approach of Basel II. This finding is consistent with the results of Aue and Kalkbrener (2007) but inconsistent with the results of Wei (2007).

The mixed bag of results produced by studies of this kind illustrate the difficulty of modelling operational risk and measuring its impact. A major problem is that of data availability and quality, implying that improvement of research on operational risk is constrained by the availability of high quality data. However, this strand of research has improved our knowledge of operational risk over a relatively short period of time. This study in particular provides new evidence on an issue not previously dealt with, which is the relation between operational losses and leverage. This issue is rather important and a topic that is worthy of future research. 


\section{References}

Atik, J. (2009) Basel II and Extreme Risk Analysis, Working Paper (Loyola Law School, Los Angeles).

Aue, F. and M. Kalkbrener (2007) LDA at Work: Deutsche Bank's Approach to Quantifying Operational Risk, Journal of Operational Risk, 1 (Winter), 49-93. Blunden, T. (2003) Scoreboard Approaches, in C. Alexander. (ed.), Operational Risk: Regulation, Analysis and Management (Prentice Hall-Financial Times, London)

Chernobai, A., P. Jorion, and F. Yu (2007) The Determinants of Operational Losses, Working Paper (Syracuse University, Syracuse, New York).

Cummins, J.D., C.M. Lewis And R. Wei (2006) The Market Value Impact of Operational Loss Events for US Banks and Insurers, Journal of Banking and Finance 30, 2605-2634.

de Fontnouvelle, P., V. Dejesus-Rueff, J. Jordan and E. Rosengren (2005) Capital and Risk: New Evidence On Implications Of Large Operational Losses, Journal of Money, Credit and Banking 38, 1819-1846.

de Mendonca, H.F., D.J.C. Galvao, and R.F.V. Loures (2011) Estimation Of Economic Capital for Operational Risk In Banking Industry: A Brazilian Case, Applied Economics Letters, 18, 485-491.

Herring, R.J. (2002) The Basel 2 Approach to Bank Operational Risk: Regulation on the Wrong Track, Paper Presented at the $38^{\text {th }}$ Annual Conference on Bank Structure and Competition, Federal Reserve Bank Of Chicago, 9 May.

Jobst, A.A. (2007) The Treatment of Operational Risk under the New Basel Framework: Critical Issues, Journal of Banking Regulation 8, 316-352. 
Karpoff, J. and J.R. Lott (1993) The Reputational Penalty Firms Bear for Committing Criminal Fraud, Journal of Law And Economics 36, 757-802.

Kilavuka, M.I. (2008) Managing Operational Risk Capital In Financial Institutions, Journal of Operational Risk 3 (Spring), 67-83.

McConnell, P. (2008) Operational Risk Capital under Basel II - Dead on Arrival? Available at www.riskmagazine.com.au.

Moosa, I.A. (2007) Operational Risk Management (Palgrave, London).

Moosa, I.A. and P. Silvapulle (2011) An Empirical Analysis of the Operational Losses of Australian Banks, Accounting and Finance (forthcoming).

Murphy, D.L., R.E. Shrieves, and S. Tibbs (2004) Determinants of the Stock Price Reaction to Allegations of Corporate Misconduct: Earnings, Risk, and Firm Size Effects, Working Paper (University Of Tennessee, Knoxville).

Palmrose, Z., R.E. Richardson, and S. Scholz (2004) Determinants of Market Reactions to Restatement Announcements, Journal of Accounting and Economics 37, 59-89.

Perry, J. and P. de Fontnouvelle (2005) Measuring Reputational Risk: The Market Reaction to Operational Loss Announcements, Working Paper (Federal Reserve Bank of Boston, Boston, MA).

Petersen, M.A. and J. Mukuddem-Petersen (2005) Stochastic Behaviour of RiskWeighted Bank Assets under the Basel II Capital Accord, Applied Financial Economics Letters, 1, 133-138.

Pezier, J. (2003) A Constructive Review of The Basel Proposals on Operational Risk, In C. Alexander (ed), Operational Risk: Regulation, Analysis and Management (Prentice Hall-Financial Times London). 
Power, M. (2005) The Invention of Operational Risk, Review Of International Political Economy 12, 557-599.

Shih, J., A. Samad-Khan and P. Medapa (2000) Is The Size of an Operational Loss Related To Firm Size? Operational Risk, January, 1.

Sundmacher, M. (2007) Operational Risk Capital Charges for Banks: Consideration and Consequences. Available at http://ssrn.com/abstratct=988227.

Wei, R. (2003) Operational Risk in The Insurance Industry, Working Paper (Wharton School, Philadelphia)

Wei, R. (2006) An Empirical Investigation of Operational Risk in the United States Financial Sector, Working Paper (Wharton School, Philadelphia).

Wei, R. (2007) Quantification of Operational Losses Using Firm-Specific Information and External Databases, Journal of Operational Risk 1 (Winter), 3-34. 
Table 1: Classification of Losses by Business Line and Event Type

\begin{tabular}{|ccccccccc|}
\hline Severity (USD million) & BDSF & CPBP & EDPM & EF & EPWS & IF & Other & Total \\
\hline AM & 0.0 & 471.6 & 2.1 & 0.0 & 0.0 & 654.6 & 0.0 & 1128.3 \\
CB & 0.0 & 321.2 & 0.0 & 267.3 & 0.0 & 12.2 & 622.6 & 1223.4 \\
CF & 0.0 & 83.3 & 0.1 & 0.0 & 1.6 & 0.0 & 585.7 & 670.7 \\
PS & 0.0 & 165.0 & 0.0 & 20.2 & 0.0 & 1.1 & 0.0 & 186.3 \\
RB & 29.5 & 485.8 & 160.4 & 72.2 & 0.0 & 16.8 & 127.4 & 892.2 \\
TS & 0.0 & 321.7 & 15.0 & 0.0 & 3.5 & 63.4 & 636.0 & 1039.6 \\
Other & 28.3 & 1724.4 & 468.4 & 52.7 & 39.1 & 1467.4 & 7149.6 & 10929.9 \\
Total & 57.8 & 3573.0 & 646.1 & 412.4 & 44.2 & 2215.4 & 9121.3 & 16070.3 \\
& & & & & & & & \\
\hline Frequency (No) & BDSF & CPBP & EDPM & EF & EPWS & IF & Other & Total \\
\hline AM & 0 & 14 & 3 & 0 & 0 & 3 & 0 & 20 \\
CB & 0 & 3 & 0 & 5 & 0 & 5 & 3 & 16 \\
CF & 0 & 2 & 1 & 0 & 1 & 0 & 1 & 5 \\
PS & 0 & 1 & 0 & 3 & 0 & 1 & 0 & 5 \\
RB & 1 & 11 & 2 & 4 & 1 & 4 & 1 & 24 \\
TS & 0 & 19 & 3 & 0 & 1 & 5 & 1 & 29 \\
Other & 2 & 29 & 7 & 3 & 9 & 6 & 8 & 64 \\
Total & 3 & 79 & 16 & 15 & 12 & 24 & 14 & 163 \\
\hline
\end{tabular}

AM: asset management; CB: commercial banking; CF: corporate finance; PS: payment and settlement; RB: retail banking; TS: trading and sales; BDSF: business disruption and system failures; CPBP: clients, products and business practices; EDPM: execution, delivery and process management; EF: external fraud; EPWS: employment practices and workplace safety; IF: internal fraud; Other: events and business lines that do not fall under any of the BCBC categories. 
Table 2: Classification of Losses by Event Type and Corporate Entity Type

\begin{tabular}{|c|c|c|c|c|c|c|c|c|}
\hline Severity (USD million) & BDSF & СРВP & EDPM & $\mathrm{EF}$ & EPWS & IF & Other & Total \\
\hline Aerospace & 0.0 & 9.3 & 0.0 & 6.5 & 0.0 & 0.0 & 77.2 & 93.0 \\
\hline Computer Hardware & 0.0 & 0.0 & 0.0 & 0.0 & 0.3 & 0.0 & 0.0 & 0.3 \\
\hline Corporate Conglomerates & 0.0 & 35 & 0.0 & 0.0 & 0.0 & 0.0 & 14.1 & 17.6 \\
\hline Energy & 0.0 & 0.2 & 0.0 & 0.0 & 0.0 & 0.0 & 0.0 & 0.2 \\
\hline Food \& Beverage & 0.0 & 47.0 & 0.0 & 0.0 & 0.0 & 0.0 & 1.0 & 48.0 \\
\hline Publishing \& Media & 0.0 & 0.0 & 0.0 & 0.0 & 0.0 & 859.3 & 0.0 & 859.3 \\
\hline Retail & 0.0 & 56.4 & 0.0 & 0.0 & 0.2 & 0.0 & 0.0 & 56.7 \\
\hline Telecommunications & 0.0 & 31.5 & 0.0 & 0.0 & 0.0 & 0.0 & 6231.6 & 6263.1 \\
\hline Transportation & 0.0 & 546.3 & 0.0 & 0.0 & 0.0 & 0.0 & 0.0 & 546.3 \\
\hline Utilities & 28.2 & 0.0 & 37.0 & 0.0 & 0.0 & 0.0 & 0.0 & 65.3 \\
\hline Commercial Banks & 0.0 & 1231.7 & 199.8 & 385.4 & 11.2 & 740.9 & 1844.3 & 4413.3 \\
\hline Investment Banks & 0.0 & 427.7 & 10.1 & 0.0 & 11.9 & 1.4 & 0.0 & 451.0 \\
\hline Mortgage Banks & 0.0 & 397.2 & 0.0 & 0.0 & 0.0 & 0.0 & 0.0 & 397.2 \\
\hline Retail Banks & 29.5 & 61.0 & 1.2 & 11.3 & 0.0 & 1.4 & 0.0 & 104.5 \\
\hline Brokerage & 0.0 & 104.1 & 0.0 & 0.0 & 0.0 & 8.9 & 0.0 & 113.0 \\
\hline Insurance Companies & 0.1 & 478.9 & 250.6 & 9.2 & 18.4 & 2.6 & 953.1 & 1712.8 \\
\hline Management Companies & 0.0 & 177.7 & 0.0 & 0.0 & 2.2 & 600.0 & 0.0 & 779.8 \\
\hline Hedge Funds & 0.0 & 0.1 & 0.4 & 0.0 & 0.0 & 0.0 & 0.0 & 0.4 \\
\hline Delivery Services & 0.0 & 0.0 & 147.0 & 0.0 & 0.0 & 0.0 & 0.0 & 147.0 \\
\hline Outsourcing & 0.0 & 0.6 & 0.0 & 0.0 & 0.0 & 1.1 & 0.0 & 1.7 \\
\hline Total & 57.8 & 3573.1 & 646.0 & 412.4 & 44.2 & 2215.5 & 9121.3 & 16070.3 \\
\hline Frequency & BDSF & СРВP & EDPM & $\mathrm{EF}$ & EPWS & $\mathrm{IF}$ & Other & Total \\
\hline Aerospace & 0 & 2 & 0 & 1 & 0 & 0 & 1 & 4 \\
\hline Computer Hardware & 0 & 0 & 0 & 0 & 1 & 0 & 0 & 1 \\
\hline Corporate Conglomerates & 0 & 2 & 0 & 0 & 0 & 0 & 1 & 3 \\
\hline Energy & 0 & 1 & 0 & 0 & 0 & 0 & 0 & 1 \\
\hline Food \& Beverage & 0 & 1 & 0 & 0 & 0 & 0 & 1 & 2 \\
\hline Publishing \& Media & 0 & 0 & 0 & 0 & 0 & 1 & 0 & 1 \\
\hline Retail & 0 & 2 & 0 & 0 & 1 & 0 & 0 & 3 \\
\hline Telecommunications & 0 & 1 & 0 & 0 & 0 & 0 & 1 & 2 \\
\hline Transportation & 0 & 1 & 0 & 0 & 0 & 0 & 0 & 1 \\
\hline Utilities & 1 & 0 & 1 & 0 & 0 & 0 & 0 & 2 \\
\hline Commercial Banks & 0 & 25 & 5 & 12 & 5 & 14 & 5 & 66 \\
\hline Investment Banks & 0 & 6 & 3 & 0 & 2 & 3 & 0 & 14 \\
\hline Mortgage Banks & 0 & 5 & 0 & 0 & 0 & 0 & 0 & 5 \\
\hline Retail Banks & 1 & 6 & 1 & 1 & 1 & 1 & 0 & 11 \\
\hline Brokerage & 0 & 4 & 0 & 0 & 0 & 2 & 0 & 6 \\
\hline Insurance Companies & 1 & 14 & 3 & 1 & 1 & 1 & 5 & 26 \\
\hline Management Companies & 0 & 7 & 0 & 0 & 1 & 1 & 0 & 9 \\
\hline Hedge Funds & 0 & 1 & 2 & 0 & 0 & 0 & 0 & 3 \\
\hline Delivery Services & 0 & 0 & 1 & 0 & 0 & 0 & 0 & 1 \\
\hline Outsourcing & 0 & 1 & 0 & 0 & 0 & 1 & 0 & 2 \\
\hline Total & 3 & 79 & 16 & 15 & 12 & 24 & 14 & 163 \\
\hline
\end{tabular}


Table 3: Results of Testing Hypotheses 1-4

\begin{tabular}{|lcccc|}
\hline & H1 & H2 & H3 & H4 \\
\hline Test Statistic $\left(\chi^{2}\right)$ & 6760.0 & 65.5 & 2996.1 & 156.7 \\
Degrees of Freedom & 36 & 36 & 120 & 120 \\
5\% Critical Value & 51.0 & 51.0 & 146.6 & 146.6 \\
$1 \%$ Critical Value & 58.6 & 58.6 & 159.0 & 159 \\
\hline
\end{tabular}


Table 4: Results of Testing Hypotheses 6-7

\begin{tabular}{|c|c|c|}
\hline & $\Delta V / L$ & $L$ \\
\hline $\bar{X}_{1}$ & 1.170 & 92.31 \\
\hline $\bar{X}_{2}$ & 1.251 & 99.68 \\
\hline$s_{1}^{2}$ & $3.90 \times 10^{4}$ & $2.71 \times 10^{11}$ \\
\hline$s_{2}^{2}$ & $1.95 \times 10^{2}$ & $2.55 \times 10^{11}$ \\
\hline$n_{1}$ & 24 & 24 \\
\hline$n_{2}$ & 139 & 139 \\
\hline$t$ & -0.15 & -0.00007 \\
\hline
\end{tabular}


Table 5: Results of Testing Hypotheses 8-10

\begin{tabular}{|cccc|}
\hline & Equation (14) & Equation (15) & Equation (16) \\
\hline$\alpha_{1}$ & 115.29 & & \\
& $(2.36)$ & & \\
$\beta_{1}$ & -0.00006 & & \\
& $(-0.79)$ & & \\
$\alpha_{2}$ & & $(5.11)$ & \\
& & -0.09 & \\
$\beta_{2}$ & $(-0.47)$ & $(0.80)$ \\
& & & 0.003 \\
$\alpha_{3}$ & & $(2.96)$ \\
$\beta_{3}$ & & -7.77 \\
& & & $(-0.51)$ \\
$\gamma_{3}$ & & & 0.060 \\
\hline$R^{2}$ & & & \\
\hline
\end{tabular}


Figure 1: Frequency and Severity of Operational Loss Events (1999-2007)

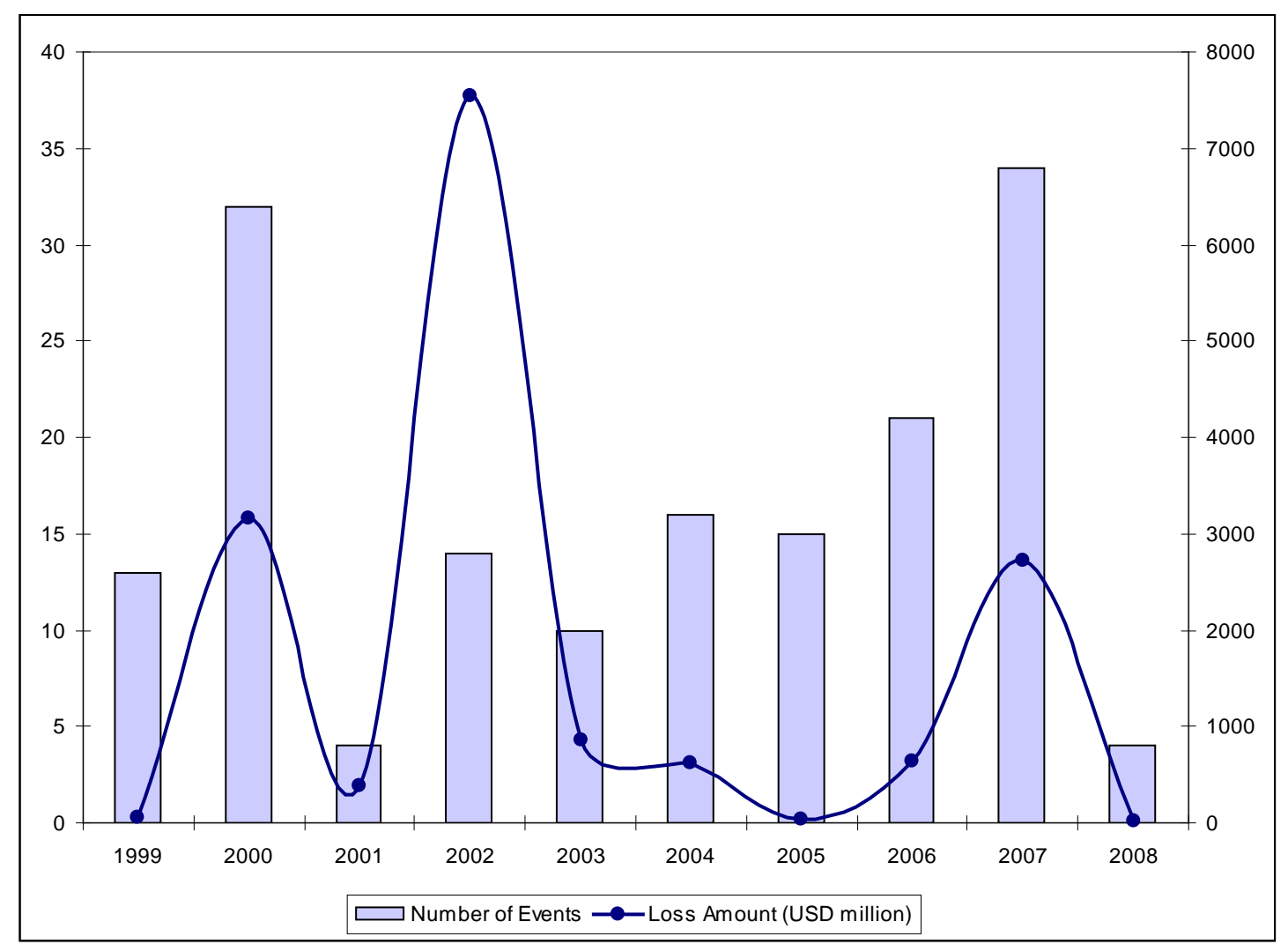


Figure 2: Frequency and Severity by Business Line and Event Type

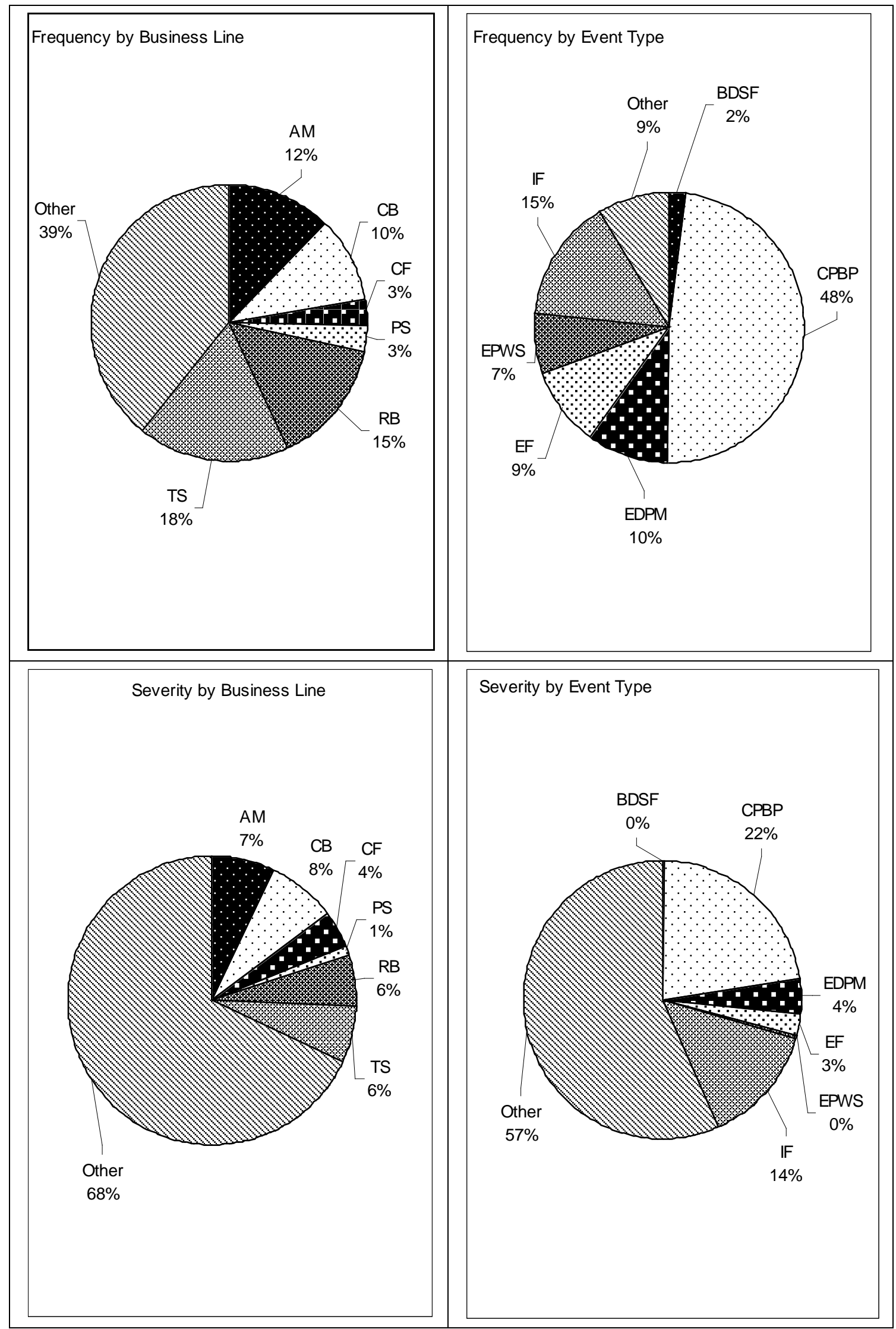


Figure 3: Frequency and Severity by Entity Type

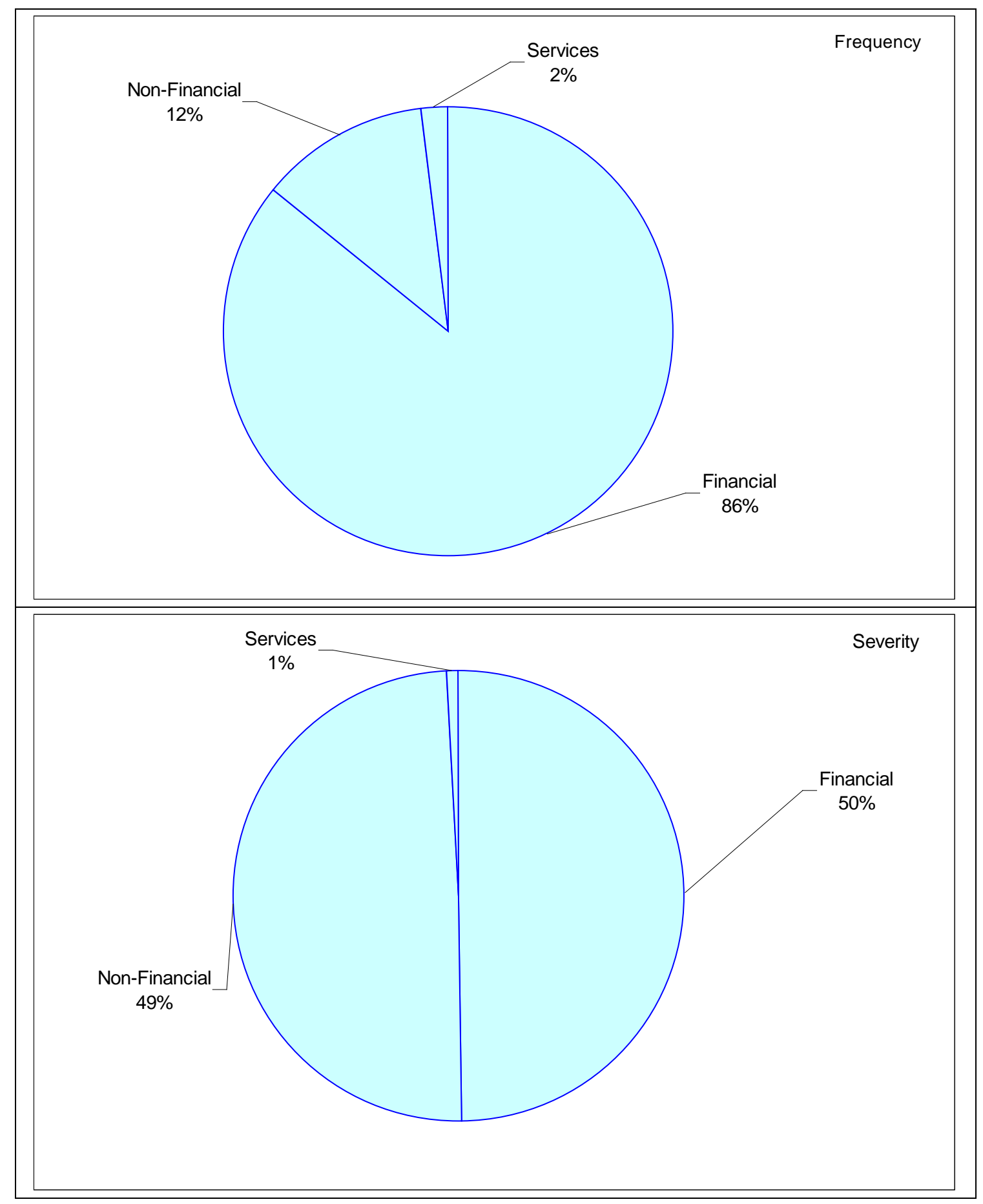


Figure 4: Test Statistics for Hypothesis 5

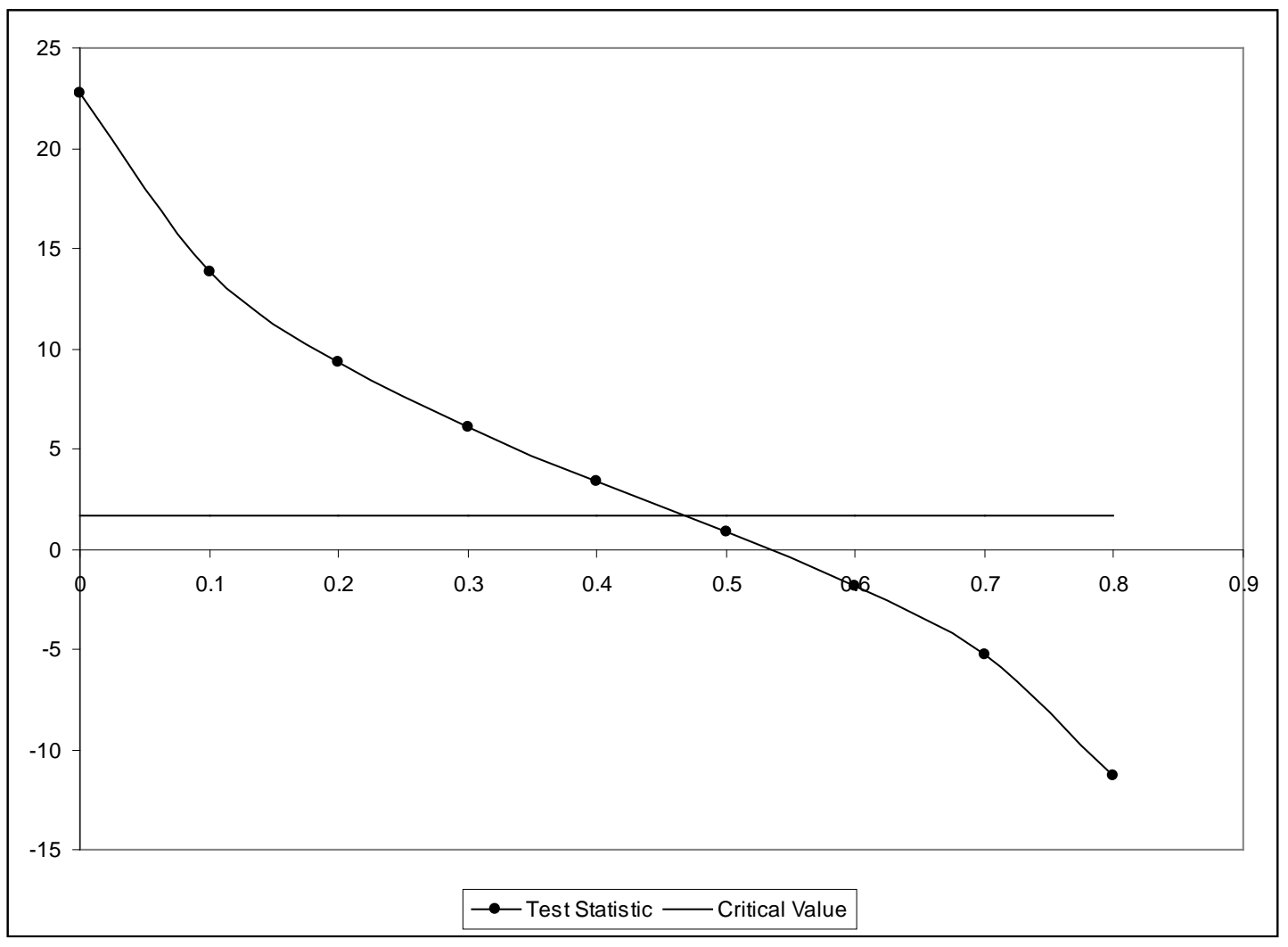

